\title{
PROMOTING TOURISM DESTINATION THROUGH FILM-INDUCED TOURISM: THE CASE OF JAPAN
}

\section{PROMOCIJA TURISTIČKE DESTINACIJE PUTEM FILMSKOG TURIZMA: SLUČAJ JAPANA}

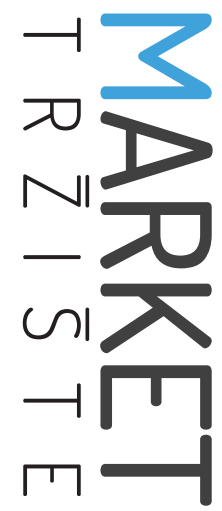

Market-Tržište

Vol. 29, No. 2, 2017, pp. 193-203

UDK 338.48-61:791.43(520)

DOl http://dx.doi.org/10.22598/mt/2017.29.2.193

Review

\section{Wadim Strielkowski}

Judge Business School, University of Cambridge, 13 Trumpington street, Cambridge CB2 1AG, UNITED KINGDOM, strielkowski@cantab.net

\begin{abstract}
Purpose - This paper describes the marketing potential of film-induced tourism in marketing Japan, as a popular tourism destination for non-Asian visitors. In particular, it focuses on the popular culture and on engaging young people from Europe, America, and Australia in discovering and promoting its cultural heritage.
\end{abstract}

Design/Methodology/Approach - The number of Western tourists to Japan rose by 50 \% between 2010 and 2015. Many of these tourists are attracted by the films associated with Japan in one way or another. We assume that, even though the majority of incoming tourists in Japan are Chinese visitors, the marketing potential of film-induced tourism in Japan represents a source of untapped potential. One can trace the increase in the popularity of Japan as the tourism destination to a number of new Western films taking place in Japan.

Findings and implications - We employ the monthly data on the combined box office revenues of recent films set in Japan, as well as the monthly statistics on the number of visitors from Australia, Europe, and North America. We find causality between the popularity of the films and the number of tourists from the destinations that are mostly impacted by those films.

Limitations - The research is limited by the issue of popularity of Western culture and films in Asia. One should

\section{Sažetak}

Svrha - Rad opisuje marketinški potencijal filmskog turizma u marketingu Japana kao popularne turističke destinacije za posjetitelje iz neazijskih zemalja. Posebno se usredotočuje na popularnu kulturu i uključivanje mladih Ijudi iz Europe, Amerike i Australije u otkrivanje i promoviranje japanske kulturne baštine.

Metodološki pristup - Od 2010.-2015. godine u Japanu je broj turista iz zapadnih zemalja porastao za 50\%. Mnoge od njih privukli su filmovi povezani s Japanom na jedan ili drugi način. lako su većina turista koji dolaze u Japan kineski posjetitelji, pretpostavlja se da je marketinški potencijal izazvan filmskim turizmom u Japanu izvor neviđenoga potencijala. Povećanje popularnosti Japana kao turističke destinacije može se pripisati brojnim novim filmovima sa Zapada čija se radnja odvija u Japanu.

Rezultati i implikacije - Upotrijebljeni su mjesečni podaci, kombinacija prihoda s box office-a (blagajni) nedavnih filmova s radnjom smještenom u Japanu i statistike o broju posjetitelja iz Australije, Europe i Amerike. Pronađena je kauzalnost između popularnosti filmova i broja turista iz destinacija koje su najviše pod utjecajem tih filmova.

Ograničenja - Istraživanje je ograničeno pitanjem popularnosti zapadne kulture i filmova u Aziji. Treba imati na umu činjenicu da su samo 3 od 19 milijuna stranih turista koji su posjetili Japan 2015. godine bili su turisti izvan Azije. 
remember that just 3 million out of 19 million foreign tourists that visited Japan in 2015 were non-Asian.

Originality - The popularity of films either related to or taking place in Japan is enormous in the Western world. Headed by the recent 2015 Hungarian dark comedy "Liza, the Fox-Fairy", there is a whole array of films drawing from both exotic and cosmopolitan Japanese culture. The Japanese setting offers a picturesque scenery for melodramas, such as "Lost in translation" (USD 119.7 million in box office revenues) or "Memories of a Geisha" (USD 162 million), horrors and thrillers, including "The Grudge" (USD 187 million) or "Godzilla" (USD 528 million), as well as action movies, for instance "Kill Bill Volume 1" (USD 333 million) or "The Wolverine" (USD 417 million).

Keywords - film marketing, film-induced tourism, tourism marketing, consumer preferences, Japan
Doprinos - Popularnost filmova koji su povezani s Japanom, ili čija je radnja smještena u Japanu, iznimno je velika u zapadnim zemljama. Na čelu s nedavnom mađarskom crnom komedijom iz 2015. godine "Liza, the Fox-Fairy", postoji cijeli niz filmova koji ocrtavaju egzotiku i kozmopolitizam japanske kulture. Japansko okruženje nudi pitoreskne krajolike za melodrame - „Izgubljeni u prijevodu", (119.7 milijuna američkih dolara prihoda na box office-u) ili „Sjećanja jedne gejše" (162 milijuna američkih dolara), horore i trilere- „Kletva“ (187 milijuna američkih dolara) ili Godzilla (528 milijuna američkih dolara), kao i akcijske filmove - „Kill Bill 1” (333 milijuna američkih dolara) ili „,Wolverine” (417 milijuna američkih dolara).

Ključne riječi - filmski marketing, filmski turizam, turistički marketing, preferencije potrošača, Japan 


\section{INTRODUCTION}

For more than 100 years of its existence, film has allowed bringing to the audience the audiovisual capture of various ideas and stories. Thanks to the film, people can experience the adventures and emotions of heroes in distant time and space. Unlike literature (which also has a very strong influence on tourism and travel), the film is a medium that its viewer does not have to imagine the form and the shape of the streets, interiors, scenery, or the main protagonists of the film (Herbert, 2001; Hudson \& Ritchie, 2006a; Roesch, 2009; Connell, 2012; O'Connor \& Kim, 2014). The popularity of the film often translates into a desire to see the place in person, unleashing the emotions that lead to a desire to travel to the film setting or to the place associated with the film. For the past several decades, film-making has evolved dynamically and its role has changed thanks to the development of new information and communication technologies (Monaco, 2009; Chiabai, Platt \& Strielkowski, 2014). Twenty years ago, few people could own films or watch them at home at their own convenience, whereas today almost anyone can rent, own, and watch literally any film a countless number of times at no additional expense. In the past, people had to travel considerable distances to watch a screening of a film. Nowadays, there are thousands of movies readily available on the Internet or via other forms of digital and social media (quite often free of charge or at a price of a cup of coffee), so films can be watched in comfort of one's own home. The frequency of film watching has increased tenfold, thus making this medium inseparable from and very influential on people's lives (Monaco, 2009).

In the past few decades, a growing phenomenon has been observed all around the world when tourists visited destinations featured in films independently of destination tourism organizations' promotional campaigns. The tourism literature unanimously agrees that destination image largely influences tourists' choice of destinations (see, e.g. Echtner \& Ritchie, 1991;
Iwashita, 2006; Hudson \& Ritchie, 2006b; Vagionis \& Loumioti, 2011). This is how film marketing has become a popular tool for promoting tourism destinations all around the world.

Popular films can make the viewers embark on a travel in order to experience the physical properties depicted in the film (e.g. sceneries, films settings, or landscapes), or to share the emotions and attitudes linked to the actors or the storyline. Film-associated experiences are inscribed into the memory by associating them with the settings and events (see Iwashita, 2006; Hudson \& Ritchie, 2006a; Hudson \& Ritchie, 2006b).

Iwashita (2006) points out that a film can increase knowledge of certain aspects of the country, such as its nature, culture, and people which all result in the formation of positive attitudes towards the country. In turn, a positive image of the country might eventually lead to the decision to visit that country in person.

Carl, Kindon and Smith (2007) stress that such leisure activities as travelling or watching films are quite similar, since they provide a temporary relief from the daily routine of the real world. Film-induced tourism draws the crowds of tourists who either want to see the architecture, sceneries, or landscapes associated with particular films, or who are interested in experiencing the stories and themes associated with the places depicted in the films in a bid to grasp the immeasurable genius loci or to enjoy the intangible cultural heritage of the cities or rural landscapes.

With regard to that, one can mention the "push" and "pull" factors of film-induced tourism: while the push factor would be the possibility to take a break, as described by Carl and others (2007), the pull factor's impact is more complicated. It can be shown that film locations do not employ classic marketing and advertising but communicate with customers through the medium which can affect the human brain at a subconscious level. The viewers are brought to an emotional state that can hardly be achieved by classic advertising while the context of the sto- 


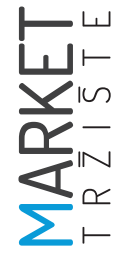

ries is offered on various sites that emotionally resonate with movies and easily arouse a desire to visit them.

Schama (1996) shows that people tend to attach both images and their personal projections to the events, locations, and actors seen in the films. Such images and projections enhance the obsession with the locations, making them iconic attractions as a result of attributing a powerful meaning to film narrations.

This paper is structured as follows: section 2 provides a comprehensive review of the tourism marketing research literature on the film-induced tourism. Section 3 describes the film-making either set in or associated with Japan in order to analyze the marketing potential of film-induced tourism in Japan. Section 4 provides some empirical results and discusses their main outcomes. Finally, Section 5 concludes the paper by providing an overall summary of the main findings and offering some policy implications both for the film industry and for the national destination marketing organizations (DMOs).

The main value-added of this paper is that it describes how films (represented by Western blockbusters) might increase the popularity of Japan as a major tourism destination. Moreover, the paper attempts to assess the marketing potential of film-induced tourism in Japan for visitors from the Western countries, as well as for the Asian tourists. To the best of our knowledge, there has never been any attempt to systemize this causality or to discuss the factors leading to the increase in the number of film-induced tourists to Japan.

\section{RECENT DEVELOPMENTS IN FILM-INDUCED TOURISM: LITERATURE REVIEW}

Despite the growing popularity of the film-induced tourism marketing, few attempts have been made to identify the critical success fac- tors behind this fast-growing phenomenon (Hudson \& Ritchie, 2006b). At present, the majority of the studies on film-induced tourism typically concentrate on Western films and on the impact of these films on the increase in the number of tourism arrivals to the destination. Riley, Baker and Van Doren (1998) stated that further research on different genres, locations and icons was important in understanding the effect of film-induced tourism, which they claim still remains under-researched and represents a rich area for theoretical exploration (see, e.g. Hudson \& Ritchie, 2006a; Bolan, Crossan \& O'Connor, 2008; Beeton, 2004; Jia, 2009; Strielkowski, 2013; Kim \& Assaker, 2014).

Most of the visitors are attracted to the places associated with the events described in the books or depicted in films and TV series. However, the majority of these events might be a result of a pure imagination of their creators and have never actually taken place in real life. The same goes to the tourist destinations. They play an important role in film-induced tourism marketing, although the plot of most films does not tie them to any specific location or places them in various locations, quite often all around the world. The two best examples of this fact are the popular film series "Harry Potter" and "Lord of the Rings" set in the United Kingdom and New Zealand. New Zealand is one of the most recent destinations to have benefited largely from film-induced tourism. The image of the country has been further reinforced since it has been the setting of the three "Lord of the Rings" films, so the New Zealand Tourism has promoted the country as the "Home of Middle-Earth" (see Jones \& Smith, 2005; Hudson \& Ritchie, 2006a; Carl et al., 2007; O'Connor \& Kim, 2014).

Another interesting example is the famous British film "Trainspotting", based on the novel of Irvine Welsh and directed by Danny Boyle in 1996. Although it was shot in Glasgow, crowds of tourists have visited Edinburgh in search of the sites and locations associated with the film's storyline (see, e.g. Di Cesare, D'Angelo \& Rech, 2009). And this is not to mention the literature 
marketing that coincides with the film marketing in a number of ways. Most of the successful literary works today are forged into successful films and TV series which increase their popularity and dissemination. TV series appear to be even more powerful than films since they can continuously reinforce the appeal of the destination and create the addiction, familiarity, and awareness (Kim, 2012).

In this context, Vagionis and Loumioti (2011) demonstrate that film-induced tourism might be an effective marketing tool for promoting tourism destinations. Reeves (2001) points out that not only "feeling good" or "being associated with romance or escapism" constitutes a popular visitor attraction. Previously unknown towns such as Burkittsville, Maryland in the United States - the setting of "The Blair Witch Project" - experienced an influx of visitors after it was aired, and the Georgetown house in Washington D.C., which was the setting for cult horror film "The Exorcist", continues to be a major tourist attraction. Beale (2012) claims that thanks to the "Twilight Series" set by Stephenie Meyer in a little town of Forks, at Olympia Peninsula in Washington, the local economy experienced a huge tourism boost: in 2008, after the release of the first of the films, the number of visitors nearly doubled to 19,000 only to reach 73,000 people by 2010.
Table 1 shows the impact of films on the number of visitors using the example of several blockbuster films and blockbuster film series (those including a series of sequels and often turning into profitable film franchises). One can observe an increase ranging from $22 \%$ in the first year after release in the case of "The Beach" directed by Danny Boyle to up the 700 \% increase in the case of "The Twilight Saga" films (a series of five films).

There are similar stories in Asia too. For instance, Seaton and Yamamura (2015) show that the phenomenon of foreign tourists visiting Japanese locations thanks to domestically produced films was made evident in connection with the Chinese hit film "If you are the one", which sparked a Chinese tourism rush to Eastern Hokkaido in 2008.

Overall, it seems that films might bring considerable profits to the locations whether they are associated with them or operate with easily recognizable places. However, while some of the towns and cities that appeared in films seem to profit from that fact, others cannot fully exploit their tourism potential. For instance, it was reported that the local community of Burkittsville, Maryland, U.S. (the setting of "The Blair Witch Project") claims that the successful film has brought the "unwanted popularity and

TABLE 1: Impact of films on the number of visitors

\begin{tabular}{|c|l|l|l|}
\hline Year & \multicolumn{1}{|c|}{ Film } & Location & $\begin{array}{c}\text { Increase in the number } \\
\text { of visitors }\end{array}$ \\
\hline $2008-2012$ & The Twilight Saga & Forks, Washington, U.S. & $700 \%$ in the first year after release \\
\hline $2001-2011$ & Harry Potter & Various locations in the UK & $50 \%$ in all locations \\
\hline 2004 & Troy & Turkey & $73 \%$ in location of old Troy \\
\hline 2001 & $\begin{array}{l}\text { Captain Corelli's } \\
\text { Mandolin }\end{array}$ & Greece & $50 \%$ in the years after release \\
\hline 2000 & The Beach & Thailand & $22 \%$ in youth market \\
\hline 1999 & Notting Hill & Notting Hill, London & $120 \%$ in one year after release \\
\hline 1995 & Braveheart & $\begin{array}{l}\text { Wallace Monument, } \\
\text { Scotland }\end{array}$ & $300 \%$ in one year after release \\
\hline
\end{tabular}

Source: Own compilations and calculations based on Reeves (2001), Di Cesare et al. (2009), Vagionis \& Loumioti (2011), and Beale (2012). 


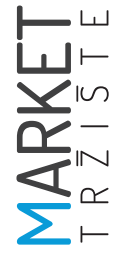

troubles" upon their small community, while the profits from increased film-induced tourism remained negligible and possible damages far surpassed the profits (Fiore, 2010).

Therefore, the popularity of certain locations brought about by popular films (or films with the so-called "cult" status) might also backfire on them. One has to agree that the construction of cult status represents alchemy of sorts. It is nearly impossible to acquire cult status on demand. Moreover, the cult of any film typically starts with a smaller but extremely dedicated fan base that expresses a keen interest in the film in the long run (Fisher \& Smith, 2010).

\section{MARKETING POTENTIAL OF FILM-INDUCED TOURISM IN JAPAN}

Japan has always been a major film destination that gave the world Akira Kurosawa (1910-1998), the legendary film maker and cinema legend with cult status. Kurosawa's success with the film "Rashomon", which received the Golden Lion at the Venice Film Festival in 1951, opened up Western film markets to Japanese films and contributed to the overlap of both film-making cultures (Kinnia, 2009).

Moreover, the popularity of films either related to or taking place in Japan is enormous in the Western world (see Beeton, Yamamura \& Seaton, 2013). Although most of these films' crew and cast have never set their foot in Japan (some typical destinations for shooting that are envisaged to substitute for real Japan often include Australia, New Zealand, or California), the stories are set in the country or are at least related to Japanese culture, music, or mythology (sometimes all three). This is the case with the 2015 Hungarian dark comedy entitled "Liza, the Fox-Fairy" ("Liza, a rókatündér"), directed by
Károly Ujj Mészáros and starring Mónika Balsai and Danish-Japanese actor David Sakurai, which won the Grand Prize at the Fantasporto Film Festival in Portugal and became a rampaging success in both its home Hungary and other European countries (Pinto, 2015). The film tells the story of Liza, a 30-year old nurse who is taking care of a widow of a Japanese ambassador in the fictional 1960s capitalist Hungary. Liza is fascinated by the Japanese culture and has a secret friend, a ghost of the imaginary Japanese singer Tomy Tani, with whom she sings swing-inspired songs in Japanese. However, Liza also has a curse - she is doomed to be a fox-fairy and kills all men who fall in love with her. This witty dark comedy that draws from the Japanese legends about fox-fairies and plays with the elements of Japanese culture (the film is full of sequences of protagonists dressed in traditional kimonos and walking around cherry-blossomed river hills, lined with the snow-covered mountains at the horizon) and music is a typical example of how the Western audience associates Japan with an unknown, yet attractive country. At the end of the film, Liza and her family are shown as they travel to see the Nasu region in Japan which is allegedly famous for its fox-fairies.

Grihault (2003) argues that the success of films can be used as a good predictor for the tourism arrivals that are induced by a particular film. With regard to that, one can recall a plethora of commercially successful Western films that exploited exotic and cosmopolitan Japanese culture. The list includes a variety of films of literary all possible genres, including: melodramas ("Lost in translation" or "Memories of a Geisha"), horrors and thrillers ("The Grudge" or "Godzilla"), as well as action movies ("Kill Bill Volume 1" or "The Wolverine"), all of which take place in Japan. Table 2 lists Western blockbuster films set in Japan that were released between 2003 and 2015. 
TABLE 2: Blockbuster films set in Japan (2003-2015)

\begin{tabular}{|l|l|l|l|c|}
\hline Year & \multicolumn{1}{|c|}{ Film } & \multicolumn{1}{|c|}{ Location } & \multicolumn{1}{c|}{ Starring } & $\begin{array}{c}\text { Box office } \\
\text { revenue } \\
\text { (USD mil.) }\end{array}$ \\
\hline 2015 & Liza, the Fox-Fairy & Nasu & Mónika Balsai, David Sakurai & n//a \\
\hline 2014 & Godzilla & Tokyo & Aaron Taylor-Johnson, Ken Watanabe & 528 \\
\hline 2013 & The Wolverine & Nagasaki, Tokyo & Hugh Jackman, Hiroyuki Sanada & 417 \\
\hline 2013 & 47 Ronin & locations in Japan & Keanu Reeves & 151 \\
\hline 2012 & Emperor & Tokyo & Tommy Lee Jones, Matthew Fox & 14.67 \\
\hline 2010 & Inception & Tokyo & Leonardo DiCaprio, Ken Watanabe & 825.5 \\
\hline 2006 & The Grudge 2 & Tokyo & $\begin{array}{l}\text { Amber Tamblyn, Sarah Michelle } \\
\text { Gellar }\end{array}$ & 70.7 \\
\hline 2006 & $\begin{array}{l}\text { The Fast and the } \\
\text { Furious:Tokyo drift }\end{array}$ & Tokyo & Lucas Black, Bow Wow & 158.4 \\
\hline 2006 & Babel & Tokyo & Brad Pitt, Cate Blanchett & 135.3 \\
\hline 2005 & $\begin{array}{l}\text { Memories of a } \\
\text { Geisha }\end{array}$ & Kyoto & Zhang Ziyi, Gong Li & 162 \\
\hline 2004 & The Grudge & Tokyo & Sarah Michelle Gellar, Jason Behr & 187 \\
\hline 2003 & Kill Bill Volume 1 & Okinawa, Tokyo & Uma Thurman, Lucy Liu & 333 \\
\hline 2003 & Lost in translation & Tokyo, Kyoto & Bill Murray, Scarlet Johansson & 119.7 \\
\hline 2003 & The Last Samurai & Kyoto, Himeji & Tom Cruise, Ken Watanabe & 456.7 \\
\hline
\end{tabular}

Source: Own compilations based on Box Office Mojo (2016)

Yamamura (2015) shows that the use of the media mix in the official promotional strategies regarding film-induced tourism really took off in Japan in the 1990s. He identifies three key periods: i) the 1990s, when multi-use between manga, anime and games flourished; ii) the early 2000s, when the Internet made the digital production and sharing of contents accessible to a vast number of people; and iii) from the 2000s onwards, when local communities can be viewed as "media" themselves because they have become involved in the production and marketing of contents, and their spaces are becoming mediatized (e.g. tangible and intangible heritage).

According to Yamamura (2015), the third stage in which geographical place and contents get linked together in a commercial partnership is when the economic potential for contents tourism emerges more strongly.

Over the last six years, the number of tourists visiting Japan has almost doubled (from 6 mil- lion in 2009 to almost 13 million in 2014). Figure 1 shows the total number of tourists visiting Japan in 2009-2015, highlighting the share of tourists from Asia, Europe, North America, and Australia. The Japanese government and the Japan National Tourism Organization are successfully exploiting this potential.

FIGURE 1: Number of tourists visiting Japan (20092015)

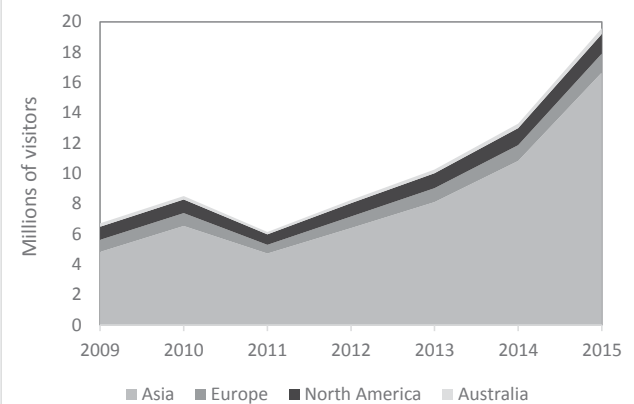

Source: Japan National Tourism Organization (2016) 
According to Seaton and Yamamura (2015), the Japanese government takes very seriously the tourism promotional strategies targeted at supporting the film-induced tourism in the country. In its own official terms, this type of tourism is called "kontentsu tsurizumu" (translated as the "contents tourism").

Out of the 19 million foreign tourists visiting Japan in 2014, no more than 3 million were nonAsian, but one can note a $50 \%$ increase in the number of Western visitors between 2010 and 2015. Although the majority of tourists visiting Japan in recent years were attracted by the shopping frenzy and the favorable exchange rate of the Japanese currency, with increasing wealth and well-being in the countries such as China and Korea also helping spur outbound tourism (see, for example, Keating, Huang, Kriz \& Heung, 2015), some of foreign tourist arrivals might have been motivated by the films that take place in Japan.

Therefore, we have attempted to construct a simple econometric model to allow us to deduce what the determinants of Japan film-induced tourism are, that is, to understand the causality between the popularity of films set in Japan and the number of incoming foreign visitors.

\section{EMPIRICAL MODEL OF JAPAN FILM-INDUCED TOURISM: METHODOLOGY AND RESULTS}

In order to depict potential relationships, the analysis related to the marketing potential of film-induced tourism in Japan is presented in the form of a cross-tabulation of key variables. The methodology is quite simple: the main goal is to establish whether the popularity of a given Japan-related film shown in cinemas worldwide had any influence on the number of tourists from Western countries. A valid sample of 48 cases was employed for the purpose of statistical analysis. The statistical test used here is the
Pearson correlation (r), employed to investigate the interdependencies between the two ratio variables.

TABLE 3: Results of the Pearson correlation (r): Japan film-induced tourism

\begin{tabular}{|c|c|c|}
\hline Film & \multicolumn{2}{|c|}{ Pearson correlation (r) } \\
\hline \multirow{3}{*}{$\begin{array}{c}\text { Emperor } \\
(2012)\end{array}$} & Australia & $\begin{array}{r}-0.199 \\
(0.534)\end{array}$ \\
\hline & Europe & $\begin{array}{c}0.142 \\
(0.657)\end{array}$ \\
\hline & North America & $\begin{array}{c}0.477 \\
(0.116)\end{array}$ \\
\hline \multirow{3}{*}{$\begin{array}{l}47 \text { Ronin } \\
\text { (2013) }\end{array}$} & Australia & $\begin{array}{l}0.586^{* *} \\
(0.044)\end{array}$ \\
\hline & Europe & $\begin{array}{l}0.511^{* *} \\
(0.089) \\
\end{array}$ \\
\hline & North America & $\begin{array}{c}0.474 \\
(0.118) \\
\end{array}$ \\
\hline \multirow{3}{*}{$\begin{array}{c}\text { The } \\
\text { Wolverine } \\
\text { (2013) }\end{array}$} & Australia & $\begin{array}{c}0.108 \\
(0.736)\end{array}$ \\
\hline & Europe & $\begin{array}{l}0.326^{* *} \\
(0.099)\end{array}$ \\
\hline & North America & $\begin{array}{l}0.048^{*} \\
(0.122)\end{array}$ \\
\hline \multirow{3}{*}{$\begin{array}{l}\text { Godzilla } \\
\text { (2014) }\end{array}$} & Australia & $\begin{array}{l}0.695^{* *} \\
(0.012)\end{array}$ \\
\hline & Europe & $\begin{array}{l}0.031^{* *} \\
(0.092) \\
\end{array}$ \\
\hline & North America & $\begin{array}{c}0.163^{* * *} \\
(0.006)\end{array}$ \\
\hline
\end{tabular}

Note: p-values significant at the level of: $1 \%(* *), 10 \%(* *)$, and $15 \%\left(^{*}\right)$.

Source: Own results

We employ the monthly data on the combined box office revenues of four recent films set in Japan: "Emperor" (2012), "47 Ronin" (2013), "The Wolverine" (2013), and "Godzilla" (2014), as well as the monthly statistics on the number of foreign visitors to Japan coming from Australia, Europe, and North America. The data has been obtained from the Japan National Tourism Organization and the Box Office Mojo (2016), film box office revenues data, representing the numbers of visi- 
tors and millions of USD made in movie theaters worldwide.

Our aim was to test whether there exists any statistically significant correlation between the popularity of recent Hollywood blockbusters set in Japan and the number of foreign visitors (delayed by one month) from Western countries who are drawn to this country. The delay period of one month was chosen due to the fact that most of the Hollywood films are short-lived since they do not last more than 5-6 months after their premiere and are very soon succeeded by other new arrivals and premiers. We assume one month to be a good enough approximation of the period that might influence upon the consumer decision to choose Japan as the new travel destination when making a choice about one's travel plans and preferences.

Table 3 above reports the results of the Pearson correlation split by individual films and groups of incoming tourists.

Overall, it becomes apparent that the less successful films, such as "Emperor", hardly have any significant effect on the incoming tourism from the Western countries. In the case of "Emperor" starring Tommy Lee Jones and the "Lost" TV series starring Matthew Fox (Doctor Jack Shepard), the coefficients come through as positive and insignificant for Europe and North America and negative for Australia. These results might be reflected by the modest success of the film and its low box office revenues.

The results for the other three movies come through as positive and significant for almost all groups of tourists. "Godzilla" yields a positive and significant relationship for the tourism arrivals from all three regions in question, "The Wolverine" has the same results except for the arrivals from Australia that came through as insignificant. On the contrary, "47 Ronin" turned to be insignificant in the case of North America and positive and significant in the remaining two cases.

It should be remembered that these results are simply testing a bivariate relationship between two variables, so the relationship can change with the introduction of a third or more variables. Nevertheless, our simple test shed some light on the film-induced tourism in Japan and revealed that there might be some causality between the popularity (measured in box office revenues, as one of the most appropriate measures of success) of the films and the number of tourists from the destinations that are mostly impacted by those films. It seems that there might be an interdependence discussed earlier and deduced on the basis of the tourism research literature review.

\section{CONCLUSIONS AND POLICY IMPLICATIONS}

Overall, one might conclude that even though the major group of incoming tourists in Japan is represented by the Chinese and Koreans, who may not have even the slightest intentions to see the setting of "Godzilla" or "Lost in Translation", the marketing potential of film-induced tourism in Japan clearly may reap enormous benefits. It seems that film-induced tourism in Japan can still draw from the power of the silver screen to exploit the unused marketing potential of non-Asian visitors.

The Western culture has always been fascinated by the Japanese culture while the Asian culture took a liking to the Western megalomaniac blockbusters and bestsellers. There can be observed an increase in the popularity of Japan as the tourism destination which is related to the number and box office revenues of recent Hollywood films that are set in Japan. Western films are likely to attract both visitors from Australia, Europe, and North America and the tourists from China and Korea who are also keen viewers of Western films, who might shape their travel decisions based on the same films (although dubbed into their respective languages and renamed, as it is often done in China, to reflect consumers' tastes in the local markets).

The popularity of Japan promoted by Western films is not limited just to the Western world. It 
might as well spill over to China and other Asian countries thanks to the cumulative causation effect and thus contribute to the increase of the incoming tourism in Japan from all destinations alike. As China's GDP per capita is rocketing up, and the quality of life and well-being in the country are increasing, shopping trips to Japan might give way to cultural trips inspired by the recent films and popular culture. Since many Western films are also popular in China, it is very likely that a large share of tourists from this country might soon plan and organize their trips in such a way as to also include tours to the film-related locations.

With regard to the policy implications for the film industry and for national destination marketing organizations (DMOs), it must be noted that the Japanese government and the Japan Tourism National Organization should further employ and promote film-induced tourism as one of the most powerful tools of increasing foreign arrivals in the country. In order to reflect that, governmental policies aimed at supporting Western film-makers (e.g. by granting them tax incentives or tax holidays, offering grants for the promotion of local cultural heritage that would benefit the well-being and sustainable development of local communities) or attempts to adapt the product placement approach to increase the visibility and popularity of Japan in popular films, even those that do not necessarily take place in Japan, might bear significant results. All in all, there seems to be considerable potential that is worth exploring.

\section{References}

1. Beale, L. (2012). Hunger Games': North Carolina wants you to visit Panem. Los Angeles Times. December 10, 2012.

2. Beeton, S. (2004). Film Induced Tourism: Aspects of Tourism. Channel View Publications.

3. Beeton, S., Yamamura, T., \& Seaton, P. (2013). The mediatisation of culture: Japanese contents tourism and pop culture. In: J. Lester \& C. Scarlesc (Eds.). Mediating the tourist experience: from brochures to virtual encounters (pp. 139-154). Farnham: Ashgate.

4. Bolan, P., Crossan, M., \& O'Connor, N. (2008). Film and Television Induced Tourism in Ireland: A Comparative Impact Study of Ryan's Daughter in Ballykisangel. $4^{\text {th }}$ Annual Tourism and Hospitality Research in Ireland Conference, Tralee, Ireland.

5. Box Office Mojo (2016). Film statistics. http://www.boxofficemojo.com (accessed on January $\left.30^{\text {th }}, 2016\right)$.

6. Carl, D., Kindon, S., \& Smith, K. (2007). Tourists' experiences of film locations: New Zealand as 'Middle-Earth'. Tourism Geographies, 9(1), 49-63.

7. Chiabai, A., Platt, S., \& Strielkowski, W. (2014). Eliciting users' preferences for cultural heritage and tourism-related e-services: a tale of three European cities. Tourism Economics, 20(2), 263-277.

8. Connell, J. (2012). Film-induced tourism-Evolution, progress and prospects. Tourism Management, 33(5), 1007-1029.

9. Di Cesare, F., D'Angelo, L., \& Rech, G. (2009). Films and tourism: understanding the nature and intensity of their cause-effect relationship. Tourism Review International, 13(2), 103-111.

10. Echtner, C. M., \& Ritchie, J. B. (1991). The meaning and measurement of destination image. Journal of tourism studies, 2(2), 2-12.

11. Fiore, F. (2010). A town's 'Blair Witch' curse. Los Angeles Times. http://articles.latimes.com/2010/ may/31/nation/la-na-blair-witch-20100601 (accessed on March 29 ${ }^{\text {th }}, 2015$ ).

12. Fisher, D., \& Smith, S. (2010). Consumers bite on the social web about the film Snakes on a Plane. International Journal of Electronic Marketing and Retailing, 3(3), 241-260. 
13. Grihault, N. (2003). Film-induced tourism - The global picture. Travel \& Tourism Analyst, 5, 1-22.

14. Herbert, D. (2001). Literary places, tourism and the heritage experience. Annals of Tourism Research, 28(2), 312-333.

15. Hudson, S., \& Ritchie, J. R. B. (2006a). Promoting destination via film tourism: An empirical identification of supporting marketing initiatives. Journal of Travel Research, 44, 387-396.

16. Hudson, S., \& Ritchie, J. R. B. (2006b). Film tourism and destination marketing: The case of Captain Corelli's Mandolin. Journal of Vacation Marketing, 12(3), 256-268.

17. Iwashita, C. (2006). Media representation of the UK as a destination for Japanese tourists: Popular culture and tourism. Tourist studies, 6(1), 59-77.

18. Japan National Tourism Organization (2016). Tourism statistics. http://www.jnto.go.jp/eng/ttp/ sta/index.html (accessed on April $4^{\text {th }}$, 2016).

19. Jia, H. (2009). The construction of literary tourism site. Turizam: znanstveno-stručni časopis, 57(1), 69-83.

20. Jones, D., \& Smith, K. (2005). Middle-earth meets New Zealand: Authenticity and location in the making of The Lord of the Rings. Journal of management studies, 42(5), 923-945.

21. Keating, B. W., Huang, S., Kriz, A., \& Heung, V. (2015). A Systematic Review of the Chinese Outbound Tourism Literature: 1983-2012. Journal of Travel \& Tourism Marketing, 32(1/2), 2-17.

22. Kim, S. (2012). Audience involvement and film tourism experiences: Emotional places, emotional experiences. Tourism Management, 33(2), 387-396.

23. Kim, S., \& Assaker, G. (2014). An Empirical Examination of the Antecedents of Film Tourism Experience: A Structural Model Approach. Journal of Travel \& Tourism Marketing, 31(2), 251-268.

24. Kinnia, Y. S. (2009). Japanese and Hong Kong film industries. London: Routledge.

25. Monaco, J. (2009). How to read a film: movies, media, and beyond: art, technology, language, history, theory. $4^{\text {th }}$ ed. New York, NY: Oxford University Press.

26. O'Connor, N., \& Kim, S. (2014). Pictures and prose: exploring the impact of literary and film-induced tourism. Journal of Tourism and Cultural Change, 12(1), 1-17.

27. Pinto, V. (2015). Liza, the Fox-Fairy: A Hungarian film with an eye on Japan. http://cineuropa.org/ (accessed on January $30^{\text {th }}, 2017$ ).

28. Reeves, T. (2001). The worldwide guide to movie locations. London: Titan Publishing.

29. Riley, R., Baker, D., \& Van Doren, C. (1998). Movie Induced Tourism. Annals of Tourism Research, 25(4), 919-935.

30. Roesch, S. (2009). The experiences of film location tourists. Channel View Publications.

31. Schama, S. (1996). Landscape and memory. London: Fontana.

32. Seaton, P., \& Yamamura, T. (2015). Japanese Popular Culture and Contents Tourism - Introduction. Japan Forum, 27(1), 1-11.

33. Strielkowski, W. (2013). Mystery and thriller tourism: Novel solutions for European cities. Turizam: znanstveno-stručni časopis, 61(3), 277-287.

34. Vagionis, N., \& Loumioti, M. (2011). Movies as a tool of modern tourist marketing. Tourismos: an International Multidisciplinary Journal of Tourism, 6(2), 353-362.

35. Yamamura, T. (2015). Contents tourism and local community response: Lucky star and collaborative anime-induced tourism in Washimiya. Japan Forum, 27(1), 59-81. 